\title{
Estudio preliminar del ganglio centinela en el cáncer oral: a propósito de 12 casos
}

\author{
Preliminary study of the sentinel node in oral cancer: \\ in conjunction with 12 cases
}

\author{
C.I. Salazar Fernandez', S. Gallana Álvarez², A. Pérez Sánchez³, \\ J. Torres ${ }^{4}$, A. Rollan' 1, F. Mayorga' 1 R. Del Rosario², J.M. Pérez Sánchez ${ }^{5}$
}

Resumen: El manejo de los cuellos N0 en pacientes con carcinoma epidermoide de cabeza y cuello es controvertido.

Objetivo. Demostrar la eficacia diagnóstica de la biopsia del ganglio centinela (GC) en los pacientes con carcinoma epidermoide oral con cuello clinicamente negativo.

Metodología. Se realiza un estudio prospectivo de 12 pacientes consecutivos, hasta el momento, con carcinoma epidermoide oral de cualquier tamaño y cuello clinicamente negativo que no habian recibido tratamiento antitumoral, asistidos en el S. de Cirugía Maxilofacial del área del H.U.V.M de Sevilla. A estos pacientes se les realiza una linfografía cervical con nanocoloides -Tc 99 para localizar el GC, y una dosis de recuerdo antes de iniciar el $\mathrm{tt}^{\circ}$ quirúrgico. Durante la cirugía se localiza el GC con la sonda y se extirpa, se completa la disección cervical funcional y la extirpación de la lesión con posteriores estudios histológicos independientes.

Resultados. índice de linfolocalización: 91\%, índice de radiolocalización $100 \%$, falsos negativos $0 \%$, la sensibilidad y VPN del 100\%, cocientes de probabilidades positivo $>10$ y negativo $<0,1$.

Conclusiones. La técnica es eficaz para detectar GC-metástasico y es una guia prometedora para indicar la disección cervical (Subvención FIS 2002).

Palabras clave: Ganglio centinela; Carcinoma de células escamosas oral; Linfografía cervical; Disección cervical electiva.
Abstract: IManagement of the NO neck in patients with head and neck squamous cell carcinoma remains controversial.

Objective. To evaluate the feasibility and predictive ability of the sentinel node (SN) localization-biopsy technique for patients with squamous cell carcinoma of the oral cavity and clinically negative necks.

Methodology. We realize a prospective study of 12 consecutive patients at present, with squamous cell carcinoma oral and clinically negative necks. These patients had not recived treatment against tumor and they were assited by Maxillofacial Surgery Service of HUVM from Seville. All patients received a cervical Tc99mlymphoscintigraphy to localize the sentinel node and a new dose before surgery. Intraoperatively, the sentinel node is localized and it is removed separately before tumor resection and elective functional neck dissection. The different anatomic specimens are sent for independent histological examination.

Results. lympholocalization $91 \%$, radiolocalization 100\%, false negative $0 \%$, sensitivity and NPV $100 \%$, likely hood ratios $>10$ and likely negative ratios $<0.1$.

Conclusions. The technique allows identification of $\mathrm{SN}$-metastases and shows promise in guiding functional neck dissection (FIS-2002 subvention).

Keywords: Sentinel node; Oral squamous cell carcinoma; Cervical lymphoscintigraphy; Elective cervical dissection.

1 Médico Adjunto del Servicio de Cirugía Oral y Maxilofacial.

2 Médico Residente del Servicio de Cirugía Oral y Maxilofacial.

3 Médico Adjunto del Servicio de ORL.

4 Médico Residente del Servicio de Anatomía Patológica.

5 Jefe de Servicio de Cirugía Oral y Maxilofacial.

Hospital Universitario Virgen Macarena, Sevilla. España 


\section{Introducción}

El riesgo de sufrir metástasis cervical en el cáncer oral oscila entre el $10-45 \%$. Dicho riesgo, junto con la consideración de que si las metástasis cervicales se extirpan en estadios subclínicos, (no palpables) mejora la supervivencia en un $50 \%,{ }^{1}$ ha hecho que se haya generalizado el uso de la disección cervical profiláctica o electiva (DCE). Sin embargo, la DCE es realmente efectiva sólo en un $26 \%$ de los pacientes, con metástasis ocultas, sobretratándose el $74 \%$ de los pacientes con el grado de morbilidad y costes que conlleva. ${ }^{2}$ Por otro lado, si se opta por la vigilancia cervical, las metástasis aparecerán en el $30-40 \%$ de los pacientes precisando la disección cervical terapéutica con peor supervivencia. ${ }^{3}$ Por tanto sería realmente útil poder predecir que pacientes son los que van a presentar metástasis cervicales subclínicas, y se beneficiarían de la DCE.

Sin embargo, en el momento actual, las técnicas de diagnóstico por imagen no permiten confirmar con total seguridad la presencia de metástasis cervicales en los cuellos clínicamente negativos, como para determinar que pacientes son los que deben someterse a la disección cervical electiva en el cáncer oral. La ECO cervical parece ser el método diagnóstico que presenta mayor sensibilidad, y el PET, la mayor especificidad, en el estadiaje cervical para el cáncer oral. 4,5 Para la mayoría de los autores revisados, la sensibilidad, especificidad y exactitud de la ECO cervical, oscilan entre el $84-92,68-83$ y $76-86 \%$ respectivamente, ${ }^{4-7}$ para el PET son de $70 \%, 82 \%$ y $75 \%$ respectivamente, ${ }^{4}$ para la TC son de 66,74 y $70 \%$ respectivamente ${ }^{4,6}$ y para la RNM oscilan entre el 64-73, 69-95 y $66 \%$ respectivamente, ${ }^{4,8}$ estos valores se están intentando mejorar mediante técnicas como la RNM con oxido de hierro superparamagnético, Mack et al ${ }^{9}$ reportan una sensibilidad del $86 \%$ y una especificidad del $100 \%$ con un VPP del $100 \%$ y un VPN del $99 \%$ en un estudio realizado en 27 pacientes con esta patología.

El ganglio centinela es el primer ganglio de drenaje linfático del tumor de una localización, varios autores han demostrado para el cáncer de mama y el melanoma, que si el primer escalón del drenaje linfático (ganglio centinela) no está afectado en el estudio histológico, la posibilidad de existencia de micrometástasis es menor al 5\%. ${ }^{10-14}$ Basándose en esto, los pacientes con estos tumores recibirían el vaciamiento linfático solo cuando la biopsia del ganglio centinela presentara micrometástasis de la enfermedad. Esta técnica aplicada al carcinoma epidermoide de cabeza y cuello se encuentra aún en fase incipiente, y los escasos trabajos publicados hasta ahora dejan entrever defectos metodológicos (muestras pequeñas, de localización heterogénea, no evidencian la eficiencia diagnóstica de la técnica). ${ }^{15,16}$

\section{Objetivos}

Los objetivos de nuestro estudio son: 1. Validar la eficiencia diagnóstica de la técnica de biopsia del ganglio centinela para detectar metástasis ocultas en el carcinoma epidermoide oral TNO; 2 . Validar dicha técnica como método de estadiaje; 3 . Establecer el tipo de tratamiento cervical, lo que supondrá un cambio espectacular tanto en el tratamiento de la enfermedad como en los costes de

\section{Introduction}

The risk of suffering metastasis of the neck in oral cancer varies between $10-45 \%$. This risk together with the belief that if metastases of the neck are removed in sub-clinical (non-palpable) stages, survival rates improve by $50 \%,{ }^{1}$ has resulted in elective or prophylactic neck dissection (END) becoming generalized. However END is effective in only $26 \%$ of patients with occult metastasis, $74 \%$ are over treated with the degree of morbidity and cost that this entails. ${ }^{2}$ On the other hand, if observation of the neck is decided upon, metastasis will appear in $30-40 \%$ of patients who will need therapeutic dissection of the neck and survival rates will be worse. ${ }^{3}$ Forecasting would therefore be of great use in order to determine what patients were going to have sub-clinical metastasis of the neck and who would benefit from END.

However, current diagnostic imaging techniques do not allow confirming with total certainty the presence of cervical metastasis in clinically negative necks which would allow those patients who are to undergo END of oral cancer to be selected. Ultrasound of the neck seems to be the diagnostic method with greater sensitivity and PET scanning seems to have greater specificity for neck staging in oral cancer. ${ }^{4,5}$ For most of the authors revised sensitivity, specificity and accuracy of ultrasound of the neck varied between $84-92 \%$, 68-83\% and $76-86 \%$ respectively ${ }^{4-7}$, for PET this was $70 \%$, $82 \%$ and $75 \%$ respectively ${ }^{4}$, for CT it was $66 \%, 74 \%$ and $70 \%$ respectively 4,6 and for MRI this varied between $64-73 \%$, $69-95 \%$ and $66 \%$ respectively ${ }^{4,8}$. An attempt is being made to improve on these values using techniques such as $M R$ imaging with superparamagnetic iron oxide. Mack et al9 report sensitivity at $86 \%$, and a specificity at $100 \%$ with a PPV of $100 \%$ and a NPV of $99 \%$ in a study carried out in 27 patients with this pathology.

The sentinel node is the first lymph node into which a localized tumor will drain. Various authors have shown that, with breast cancer and melanoma, if the first stage of lymphatic drainage (sentinel node) is not affected in the histological study, the possibility of micrometastasis in less than 5\%10-14. On the basis of this, patients with these tumors will receive lymphatic drainage only when the biopsy of the sentinel node shows micrometastasis of the disease. This technique, applied to squamous cell carcinoma of the head and neck, is still in an initial stage and the comparatively little literature published to date shows methodical defects (limited samples of heterogeneous localization, do not demonstrate the diagnostic feasibility of the technique). ${ }^{15,16}$

\section{Objectives}

The objectives of the study are: 1. To evaluate the diagnostic feasibility of the sentinel node biopsy technique in order to detect occult metastasis in TNO squamous cell carcinoma of the oral cavity; 2. To evaluate this technique as 
dicho tratamiento (Fig. 1); 4. Conocer los patrones individuales de drenaje linfático del carcinoma epidermoide oral.

\section{Material y método}

Se inicia un estudio de seguimiento prospectivo de 96 pacientes consecutivos con carcinoma epidermoide oral TN0 clínico, asistidos en el Servicio de Cirugía Maxilofacial del área Hospitalaria Virgen Macarena de Sevilla a partir de Marzo del 2002.

Los criterios de inclusión en el estudio son: pacientes con carcinoma epidermoide primario confirmados mediante biopsia incisional, localizados en la cavidad oral (no se incluyen los carcinomas localizados en pilar amigdalino posterior, amígdala o faringe) con un tamaño T1-T4 N0 según la IUAC y la AJCC (valorados mediante exploración clínica y TAC cervical), que no hayan recibido ningún tipo de tratamiento antitumoral ni que presenten segundos tumores orales. Son excluidos del estudio los pacientes con alergia a los componentes del radiotrazador, las mujeres durante el periodo de embarazo o lactancia y todos los pacientes que se nieguen a participar tras la información oportuna.

La metodología del estudio se realizará en 3 fases:

1. Linfoescintigrafia. 18 h. antes de la intervención quirúrgica (extirpación del tumor y DCE), a cada paciente se le realiza una inyección submucosa peritumoral con $84 \mathrm{MBq}$ de nanocoloidesTc99m (en 4 puntos como mínimo). Esta maniobra la realiza siempre la misma persona. Seguidamente se realiza la linfoescintigrafía cervical, igualmente realizada siempre por la misma persona. Se inicia con un estudio dinámico, en sentido anterior, a los 2 minutos de la inyección, seguido de un estudio estático en sentido anteroposterior y lateral, marcándose la posición aproximada del ganglio centinela en la piel del paciente. El estudio se considera finalizado cuando se detecta el ganglio centinela o a las $24 \mathrm{~h}$. tras la inyección del nanocoloide y es valorado por 2 médicos del $\mathrm{S}$. de Medicina Nuclear de forma ciega (siempre los mismos).

2. Cirugía. Dos horas antes de iniciar la cirugía, se repite la inyección submucosa peritumoral con la misma dosis de nanocoloidesTc99m en los mismos puntos iniciales y por la misma persona. Una vez que el paciente está anestesiado, comprobamos la localización del ganglio/s centinela/s mediante un rastreo cervical cutáneo utilizando una sonda captadora de rayos gammas (navigator GPS. Tyco). Una vez localizado/s se procede a realizar la biopsia de los ganglios a staging method; 3 . To establish the type of treatment for the neck, which would result in a spectacular change in the treatment of the disease and in costs (Table 1); ${ }^{4}$ To understand the individual lymphatic drainage pattern of oral squamous cell carcinoma.

\section{Material and method}

A prospective following of 96 consecutive patients with clinical TNO oral squamous cell carcinoma were attended by the Maxillofacial Service of the Hospital Virgen Macarena of Seville from March 2002.

The criteria for being included in the study were: patients with primary squamous cell carcinoma confirmed by means of an incisional biopsy, located in the oral cavity (carcinomas localized in the posterior tonsillar pillar, the tonsils or pharynx were not included) with a size of $\mathrm{T1}$ T4 NO according to the IUAC and the AJCC (evaluated by means of clinical exploration and a cervical TAC), with no previous anti-tumor treatment nor with secondary oral tumors. Patients with allergies to the components of the radiotracer were excluded from the study, together with pregnant or nursing mothers, and patients who refused to participate having been given the relevant information.

Methodology of the study was carried out in three stages.

1. Lymphoscintigraphy. 18 hours before surgical intervention (tumor removal and END), each patient was given a submucosal injection of $84 \mathrm{MBq} 99 \mathrm{~m}$ Tc-nanocolloid (in a minimum of four points). The same person always carried this out. After this a cervical lymphoscintigraphy was done, also carried out by the same person. A dynamic study was started in an anterior sense two minutes after the injection, followed by a static study in an anterior-posterior and lateral sense, marking on the skin of the patient the approximate position of the sentinel node. The study was considered finalized when the sentinel node is detected, or 24 hours after the nanocolloid injection, and a blind evaluation was carried out by 2 doctors of the Service of Nuclear Medicine (always the same ones). 
centinelas, y posteriormente la disección cervical que engloba los niveles linfáticos del I al V. Se recoge la radiactividad del ganglio centinela in situ, de su lecho, del ganglio centinela ex situ, así como del lecho cervical y de la muestra de disección en busca de actividad residual. Los ganglios centinelas y el resto de la pieza operatoria se recogen en botes independientes para su estudio anatomopatológico, referenciando el nivel anatómico de su localización.

Consideramos un ganglio radiopositivo cuando se realiza, al menos, un contaje de 15 emisiones en 10 segundos y 3 veces el contaje que nos da su lecho quirúrgico, siendo el ganglio centinela aquel localizado en la zona marcada por la linfografía que nos de el contaje más alto.

3. Anatomía Patológica. El estudio anatomopatológico de los ganglios centinelas propugnado por la mayoría de los autores incluyen el multiseccionamiento y las técnicas de inmunohistoquímica (anticuerpos anticitoqueratinas AE1/AE3).17-20 Nosotros seguimos los pasos establecidos por Turner y cols. ${ }^{21}$ que realizan la validación histopatológica del ganglio centinela en el carcinoma epidermoide de mama, donde demuestran que si el ganglio centinela esta libre de tumor con la tinción de hematoxilina-eosina, y con las técnicas inmunohistoquímicas, la probabilidad de que un nódulo no centilena negativo para la hematoxilina-eosina esté afecto es menor de $0,1 \%$.

El estudio AP de la disección cervical (de los ganglios no centinelas mayores de $0,5 \mathrm{~cm}$ ) que se considera la prueba patrón o gold estándar consiste en:

1. Bisección hiliar o a través de su eje mayor.

2. Tinción mediante hematoxilina-eosina y estudio de una sección de 250 micras de cada mitad.

3. Los ganglios cervicales no centinelas mayores de $2,5 \mathrm{~cm}$ se procesan igual que los ganglios centinelas.

El estudio AP de los ganglios centinelas consiste en:

1. Los ganglios centinelas son seccionados a través de su hilio o su eje mayor.

2. Posteriormente se obtienen bloques de 250 micras de espesor de cada mitad del nódulo biseccionado, que se tiñen con hematoxilina-eosina. Si existe presencia de tumor, el ganglio centinela se considera positivo.

3. Si en el primer examen el ganglio centinela se considera libre de tumor, de cada mitad se obtienen sucesivas láminas de 150250 micras, para ser examinadas mediante técnicas de inmunohistoquímica. Si existen depósitos tumorales epiteliales el resultado se considera positivo.

4. Si no se detecta tumor en el paso anterior, el ganglio centinela analizado se considera negativo.

Los estudios anatomopatológicos del ganglio centinela y de la disección cervical se evaluan independientemente entre sí, y a ciegas por dos anatomopatólogos (siempre los mismos).

El seguimiento de los pacientes se realiza cada mes los 2 primeros años, cada 3 meses en el $3^{\circ}$ año y posteriormente cada 6 meses.

\section{Método estadístico}

Se calcula un tamaño muestral de 96 pacientes para un intervalo de confianza del $95 \%$ y una precisión de \pm 2 , estimando a prio-
2. Surgery. Two hours before surgery, the peritumoral submucous injection was repeated with the same dose of $99 m$ Tc-nanocolloids in the same points as at the start, and by the same person. Once the patient was anesthetized, the localization of the sentinel node/s were checked by means of cutaneous sweeping using a gamma detection probe (GPS navigator. Tyco). Once located, a biopsy of the sentinel nodes was carried out, followed by dissection of the neck which included lymphatic levels I to $V$. The radioactivity of the sentinel node was measured in situ, from the bed, from the sentinel node ex situ as well as from the cervical bed and from the dissection specimen, in order to capture residual activity. The sentinel nodes and the rest of the operative sample were placed in separate jars so that an anatomopathological study could be made in order to give the reference of the anatomic level of their localization.

We consider a node as being radiopositive when a reading of at least 15 emissions in 10 seconds is made, and when there is three times the count of the surgical bed. The sentinel node is the one located in the area marked by the lymphography which gives the highest reading.

3. Pathological Anatomy. The anatomopathological study of the sentinel nodes supported by most authors includes multisection and immunohistochemical techniques (anticytokeratin antibodies AE1/AE3)17-20. We follow the steps set out by Turner et a ${ }^{21}$, who carry out the histopathological validation of the sentinel node in squamous cell carcinoma of the breast. They showed that if the sentinel node is tumor free using hematoxylin-eosin dye and immunohistochemical techniques, the probability that a node, which is not a sentinel node and which is hematoxylin-eosin negative, could be affected is less than $0.1 \%$.

The PA study of the neck dissection (of non-sentinel nodes that are greater than $0.5 \mathrm{~cm}$ ) that is considered the quality control test or gold standard consists in:

1. Hilus bisection or through the long axis.

2. Dyeing using hematoxylin-eosin and studying a section of 250 micras of each half.

3. The non-sentinel nodes of the neck larger than $2.5 \mathrm{~cm}$ are processed in the same way as sentinel nodes.

The PA study of the sentinel nodes consists in:

1. The sentinel nodes are sectioned across the hilus or along their long axis.

2. Blocks with a thickness of 250 micras are then obtained from each half of the bi-sectioned node which are dyed with hematoxylin-eosin. If there is tumor presence the sentinel node is considered positive.

3. If on the first examination the sentinel node is considered tumor free, from each half layers of 150-200 micras are obtained in order to examine them by means of immunohistochemical techniques. If there are epithelial tumor deposits the result is considered positive.

4. If a tumor is not detected in the previous step, the sentinel node analyzed is considered negative.

The anatomopathological studies of the sentinel node and 
ri la sensibilidad de la técnica en un $99 \%$ con respecto a la prueba patrón, y aumentando un $20 \%$ por las posibles pérdidas.

La validez diagnóstica de la técnica viene dada por: La probabilidad preprueba (prevalencia); la probabilidad postprueba; la sensibilidad y especificidad (validez interna de la técnica); el valor predictivo positivo y el valor predictivo negativo (seguridad de la técnica); el cociente de probabilidades para resultados positivos (likely hood ratios) y para resultados negativos, para expresar la precisión de la técnica. Se realizarán las curvas ROC (curva de la característica operante del receptor) tras fijar determinados puntos de corte de forma que se asegure una alta sensibilidad de la prueba (evitar los posibles falsos negativos) así como la Concordancia diagnóstica entre observadores mediante el análisis de kappa / kappa ponderado.

\section{Resultados}

Se realiza la técnica del GC a 12 pacientes ( 7 hombres y 6 mujeres), con un rango de edad de 45-74 años. El tumor primario se localizó en la lengua en 5 casos, en suelo de boca en 1 caso, en encia en 4 casos y en trígono retromolar en 2 casos. Siete tumores primarios se estadiaron como T1, y 5 como T4. La linfografía cervical reveló un único GC primario en 10 casos, 2 GC primarios en 1 caso y sólo en un paciente fue mudo (Tasa de localización del GC por linfografía: 91\%). Los 11 restantes presentaron los GC en el cuello homolateral con una tasa de radiolocalización del GC del $100 \%$ de los casos. Nueve pacientes (82\%) presentaron GC anatomopatologicamente (AP) negativo, con disección cervical AP negativa, presentando un estadío TN0, y 2 pacientes (18\%) presentaron GC AP positivo y disección cervical AP positivo, presentando un estadio TN2b (IV) según la AJCC de 1997. De estos 2 pacientes GC AP positivo, uno de ellos (50\%) fue negativo, con la técnica de hematoxilina eosina y postivo con la inmunohistoquímica.

Por tanto podemos decir que la Probabilidad preprueba de presentar metástasis cervical fue $18 \%$, y la Probabilidad postprueba de presentar metástasis con la técnica GC positiva fue del 100\%. El porcentaje de falsos negativos fue del $0 \%$ y la sensibilidad del $100 \%$. La especificidad y valor predictivo positivo, por definición, son del $100 \%$ sin embargo obtenemos un valor predictivo negativo del $100 \%$ con un cociente de probabilidades positivo $(2 / 0)>10$ y un cociente de probabilidades negativo $(0 / 9)<0,1$.

Existió concordancia diagnóstica interobservador en la localización del GC en la linfografía en todos los casos excepto en 2 pacientes, mientras que existión concordancia diagnóstica interobservador en el estudio AP del GC en todos los casos.

El $27 \%$ de nuestros pacientes ( 3 casos) presentaron drenaje linfático con «salto de nivel» (GC en el nivel II en un caso, en el nivel III un caso y otro caso en el nivel IV). Un resumen de los resultados se recogen en la tabla 1.

El seguimiento de los pacientes, hasta el presente, es de 2-17 meses. Han muerto 2 pacientes, uno de ellos en el postoperatorio tardío por causa ajena al tumor (HDA), y el otro paciente por un nuevo tumor en pulmón. El resto de los pacientes estan vivos y no presentan metástasis cervical ni recidiva regional. the dissection of the neck are evaluated independently and blindly by two anatomopathologists (always the same ones).

Patient following is carried out every month for the first two years, every three months in the third year and after that every six months.

\section{Statistical method}

A sample size of 96 patients giving a confidence interval of $95 \%$ and a precision of $+/-2$, estimating a priori technical sensitivity at $99 \%$ with regard to the gold standard and increasing it by $20 \%$ because of possible losses.

The diagnostic validity is given by: The pre-test probability (prevalence); the post-test probability; sensitivity and specificity (internal value of the technique); the positive predictive value and the negative predictive value (security of the technique); the likelihood ratios for positive results and for negative results, in order to give technique precision. The $R O C$ curves are plotted (receiver operating characteristic curve) after establishing certain cut off values so that high sensitivity of the test is ensured (avoiding possible false negatives) as well as the diagnostic Concordance between observers using the kappa analysis/kappa balance.

\section{Results}

The SN technique was used on 12 patients ( 7 men and 6 women) with an age range between $45-74$ years. The primary tumor was situated on the tongue in five cases, on the floor of the mouth in one case, in the gums in four cases and in the retromolar trigone in two cases. Seven primary tumors were staged as T1 and five as T4. Lymphographies of the neck showed single primary $S \mathrm{~N}$ in ten cases, 2 primary $\mathrm{SNS}$ in one case and only in one patient was it silente (Localization rate of the SN by means of lymphography: $91 \%)$. The remaining 11 had SNs in homolateral neck with a radiolocalization SN rate of $100 \%$. Nine patients (82\%) presented negative anatomopathological (AP) SNs with negative AP neck dissection, presenting a TNO stage. Two patients (18\%) presented positive AP SNs and positive AP neck dissection presenting a TN2b (IV) stage according to the AJCC in 1997. Of these 2 patients with positive AP SNs, one (50\%) was negative with the hematoxylin-eosin technique and positive with the immunohistochemical technique.

We can therefore state that the pre-test Probability of presenting metastasis of the neck was $18 \%$ and that the post-test Probability of presenting metastasis with the positive $S N$ technique was $100 \%$. The percentage of false negatives was $0 \%$ and sensitivity was $100 \%$. The specificity and positive predictive value was by definition $100 \%$ however, we obtained a negative predictive value of $100 \%$ with a positive likelihood ratio of $(2 / 0)>10$ and a negative likelihood rate of $(0 / 9)<0.1$

There was inter-observer diagnostic concordance in the localization of the $S \mathrm{~N}$ in the lymphography in all cases except 
Tabla 1. Resumen de los resultados histologicos

\begin{tabular}{|c|c|c|c|c|c|c|c|}
\hline Pacientes & Localización & Estadio clínico & GC (n) & GC (AP) & Nivel GC & $\begin{array}{c}\text { Disección } \\
\text { cervical }\end{array}$ & Estadio AP \\
\hline 1 & Suelo & T1N0 & 2 & - & IA /IB & - & T1N0 \\
\hline 2 & Trigono & T4NO & 1 & - & I A & - & T4N0 \\
\hline 3 & Lengua & T1N0 & 1 & - & IIA & - & T1N0 \\
\hline 4 & Lengua & T1N0 & 1 & - & $1 \mathrm{~A}$ & - & T1N0 \\
\hline 5 & Lengua & T1N0 & 1 & + & III & + & $\mathrm{T} 2 \mathrm{~N} 2 \mathrm{~b}$ \\
\hline 6 & Encia & T4N0 & 1 & - & $1 \mathrm{~A}$ & - & T4N0 \\
\hline 7 & Lengua & T1N0 & 1 & - & IB & - & T1N0 \\
\hline 8 & Trigono & T1N0 & 1 & - & $1 \mathrm{~B}$ & - & T1N0 \\
\hline 9 & Encia & T4N0 & 1 & + & $1 \mathrm{~A}$ & + & T4N2b \\
\hline 10 & Encia & T4N0 & 1 & - & IV & - & T4N0 \\
\hline 11 & Encia & T4N0 & 1 & - & $1 \mathrm{~A}$ & - & T4N0 \\
\hline
\end{tabular}

Table 1. Summary of histological results

\begin{tabular}{|c|c|c|c|c|c|c|c|}
\hline Patients & Localization & Clinical stage & $\mathrm{SN}\left(\mathrm{N}^{\circ}\right)$ & SN (AP) & SN level & Neck dissection & AP staging \\
\hline 1 & Floor & T1N0 & 2 & - & $\mathrm{IA} / \mathrm{IB}$ & - & T1N0 \\
\hline 2 & Trigone & T4N0 & 1 & - & I A & - & T4N0 \\
\hline 3 & Tongue & T1N0 & 1 & - & IIA & - & T1N0 \\
\hline 4 & Tongue & T1N0 & 1 & - & $1 \mathrm{~A}$ & - & T1N0 \\
\hline 5 & Tongue & T1N0 & 1 & + & III & + & $\mathrm{T} 2 \mathrm{~N} 2 \mathrm{~b}$ \\
\hline 6 & Gums & T4N0 & 1 & - & $1 \mathrm{~A}$ & - & T4N0 \\
\hline 7 & Tongue & T1N0 & 1 & - & IB & - & T1N0 \\
\hline 8 & Trigone & T1NO & 1 & - & $1 \mathrm{~B}$ & - & T1N0 \\
\hline 9 & Gums & T4N0 & 1 & + & $1 \mathrm{~A}$ & + & T4N2b \\
\hline 10 & Gums & T4N0 & 1 & - & IV & - & T4N0 \\
\hline 11 & Gums & T4NO & 1 & - & $1 \mathrm{~A}$ & - & T4N0 \\
\hline
\end{tabular}

\section{Discusión}

El diagnóstico de las metástasis cervicales subclínicas en el carcinoma epidermoide de cabeza y cuello, constituye aún un problema importante y decisivo en el tratamiento de estos tumores. Aunque la sensibilidad de las técnicas de imagen para la detección de ganglios cervicales metastásicos está gradualmente mejorando, la especificidad permanece baja. Por ello, se han descrito técnicas de punción-aspiración guiadas por RNM y TC muy laboriosas siendo más factible la punción aspiración guiada por ultrasonido con una sensiblidad ( 98 vs $88 \%$ ), especificidad ( 95 vs $82 \%$ ) y exactitud diagnóstica (97 vs $87 \%$ ) superior a la punción aspiración convencional. ${ }^{22}$ Igualmente, surgen nuevos sistemas de valoración clinicohistologíca del tumor en relación al riesgo de metástasis cervicales como el establecido por Martinez-Gimeno y cols. ${ }^{23}$ que establecen un sistema de puntuación según varios parametros clinicohistológicos del tumor (invasión microvascular, grado de diferenciación, tamaño tumoral, espesor tumoral, infiltración inflamatoria, interfase tumoral, e invasión perineural) y su correlación con las metástasis cervicales, estableciendo un alto riesgo de metástasis cervicales para puntuaciones superiores a 17 .

El objetivo de nuestro estudio es evaluar la utilidad y aplicabilidad del GC en el cáncer oral N0 clínico para decidir el tratamiento cervical, presentando los resultados de la técnica del GC en 12 for in 2 patients. There was inter-observer diagnostic concordance in the AP study of the SNs in all cases.

$27 \%$ of our patients (3 cases) presented lymphatic drainage with «stage jumps» (SN in level II in one case, level III in another case and level IV in another). A summary of results in reflected in table $N^{\circ} 2$.

Patient following to date is of 2-17 months. 2 have died, one of them for post-operative reasons not related with the tumor (UDTH) and the other patient developed a second tumor in the lung. The other patients are alive and they do not present metastasis of the neck nor regional relapse.

\section{Discussion}

The diagnosis of sub-clinical metastases of the neck in squamous cell carcinoma of the head and neck still constitutes an important and decisive problem in the treatment of these tumors. Even though the sensitivity of the imaging techniques for metastasic node detection in the neck is gradually improving, specificity remains low. Laborious techniques have, as a result, been described using puncture-aspiration guided by MRI and CT. Puncture using ultrasound-guided aspiration is more practical with a sensitivity ratio of ( $98 \%$ 
pacientes con carcinoma epidermoide oral TNO clínico. En nuestra opinión, es muy importante establecer unos criterios bien definidos para la indicación de la técnica, igualmente consideramos la fase dinámica de la linfografía muy útil para definir la localización del GC y evitar considerar como dicho ganglio la próxima estación linfática. En nuestro estudio se consiguió una tasa de linfolocalización del $91 \%$, y una tasa de radiolocalización del $100 \%$, coincidiendo con la literatura ${ }^{24-28}$ y siempre en los primeros 15 minutos tras inyectar el trazador. En contraste con otros estudios previos ${ }^{15,29}$ hemos podido definir y extirpar un único GC en la mayoría de nuestros pacientes. Sugerimos que la extirpación del GC debe realizarse justo despues de levantar los colgajos de piel, ya que no es realista buscarlo en la pieza quirúrgica, sino que se debe asemejar a la técnica de biopsia ganglionar. Por otro lado, las interferencias de la actividad en el tumor primario en la localización del GC se pueden reducir realizando la extirpación de la lesión antes de la localización del GC o cambiando la angulación de la sonda. Con respecto a la tinción del GC con azul, nuestra experiencia es muy pobre porque dificulta la extirpación del tumor primario y estamos de acuerdo con la dificultades publicadas. $15,24,25$

En nuestro estudio presentamos una tasa de metástasis ocultas ligeramente más baja (2 pacientes: $18 \%$ ) que otros autores, 24-30,32,33 probablemente debido a una muestra aún pequeña, presentando los 2 casos un estadio AP N2b (estadio IV), de ellos 1 caso fue negativo para la hematoxilina-eosina y positivo con la técnicas de inmunohistoquímica. Villareal y cols. ${ }^{30}$ en un estudio de 22 pacientes con CA oral TNO, de 6 GC positivos uno se recapturó con las técnicas de inmunohistoquímica. Igualmente Ross, ${ }^{32}$ en su serie de 48 pacientes TN0 de orofaringe, presenta 2 casos (13\%) de GC negativo con la hematoxilina-eosina, que fueron positivos con las técnicas de inmunohistoquímica. Barzan y cols, 33 de 3 GC positivos, 2 fueron micrometástasis en su serie de 17 pacientes TN0 de orofaringe y laringe. Este hallazgo es igualmente recogido por otros autores en estudios similares.24,26-29 Por ello consideramos el análisis inmunohistoquímico y de multisección sumamente importante para la precisión de la técnica.

Nuestra tasa de falsos negativos es del $0 \%$, recogiendose en la literatura valores comprendidos entre el $0-10 \% .24-31,34-35$ El contraste de nuestros resultados con los artículos publicados más amplios, y más recientemente sobre estudios similares se recogen en la tabla 2. Por tanto, nuestro hallazgo más importante es que todas la metástasis cervicales ocultas fueron detectadas mediante un GC positivo y el poder garantizar que los pacientes que presentaron GC negativo tuvieron una disección cervical igualmente negativa. Por ello, la disección cervical estaría indicada sólo en el $18 \%$ de los casos pudiendose haber evitando en el $82 \%$ de los pacientes.

El cáncer oral no realiza un drenaje linfático escalonado desde el nivel I al nivel VI, como convencionalmente se ha creido, sino que presenta un drenaje linfático individual, como demuestra los diferentes niveles en que se encontraron los GC: El $27 \%$ de nuestros pacientes presentaron drenaje linfático individual con «salto de nivel». Ionna et al.35 en su serie de 41 pacientes con T1-2 de CA de lengua y suelo de boca encuentra «salto del escalon» en el $18 \%$ de los casos, coincidiendo con tasas similares recogidas en la literatura. 24,26-27,29,31-34 Por ello, no está justificado realizar la disección versus $88 \%$ ) specificity (95\% versus $82 \%$ ) and diagnostic accuracy $(97 \%$ versus $87 \%)$ superior to conventional puncture-aspiration. ${ }^{22} \mathrm{New}$ systems are also appearing for tumor clinico-histological evaluation in relation with the risk of metastasis in the neck, such as the one established by Martinez-Gimeno et a ${ }^{23}$ which establishes a scoring system according to various clinico-histological parameters for the tumor (microvascular invasion, differentiation grade, tumor size, tumor thickness, inflammatory infiltration, tumor interphase and perineural invasion) and their correlation with metastases of the neck, establishing a high risk of metastasis of the neck for a score of over 17.

The objective of our study was to evaluate the feasibility and applicability of the SN in clinical NO oral cancer in order to decide on treatment for the neck, using the results of the SN technique in 12 patients with clinical TNO oral squamous carcinoma. In our opinion it is very important to have well-defined criteria in order to carry out the technique, and we consider the dynamic phase of the lymphography to be equally useful for defining the location of the $\mathrm{SN}$ in order to avoid considering this same node as the next lymphatic station. In our study a $91 \%$ rate of lymph localization was achieved, and a rate of radiolocalization of $100 \%$ coinciding with the literature, ${ }^{24-28}$ and always within the first 15 minutes of injecting the tracer. In contrast with other previous studies' 15,29 we were able to locate and remove a single $S N$ in the majority of our patients. We suggest that the removal of the $\mathrm{SN}$ should be done just after lifting the skin flaps, as it would not be realistic to look for it in the surgical specimen, and the technique for a node biopsy should be followed. Also, the interferences in the activity of the primary tumor in the localization of the $\mathrm{CN}$ can be reduced by removing the lesion before localizing the $\mathrm{SN}$ or by changing the angle of the probe. We have had a very poor experience with regard to dying the $S \mathrm{~N}$ in blue as extracting the primary tumor is made more difficult, and we are in agreement with the difficulties that have been published. 15,24,25

In out study we present a hidden rate of metastasis which is slightly lower (2 patients: 18\%) than that of other authors ${ }^{24}$ 30,32,33 probably due to the small sample, both cases presenting an AP N2b stage (stage IV). Of these one case was negative with hematoxylin-eosin and positive with the immunohistochemical technique. Villareal et al. ${ }^{30}$ in a study of 22 patients with TNO oral cancer, noted that of six positive $S N$ s one was recaptured with immunohistochemical techniques. Ross et a 132 similarly, in their series with 48 patients with TNO oropharynx, presented two cases (13\%) of negative SNs with hematoxylin-eosin that were positive with immunohistochemical techniques. In their series with 17 patients with TNO oropharynx and larynx, Barzan et a/33, reported that of the 3 positive SNs, 2 had micrometastasis. This finding is equally reflected by other authors in similar studies24,26-29. We therefore consider immunohistochemical and multisection analysis of great importance for technical precision. 
Tabla 2. Resultados de estudios preliminares de la biopsia del ganglio centinela en el cancer oral, de cavun y orofaringe

$\begin{array}{lccccc}\text { Autores } & \text { Pacientes (n) } & \text { Linfolocalización } & \text { Radiolocalización } & \text { N Ocultas } & \text { Falsos negativos } \\ \text { Stoeckli24 }^{24} & 19 & 94,7 \% & 100 \% & 31,5 \% & 0 \% \\ \text { Shoaib }^{26} & 40 & 90 \% & 100 \% & 50 \% & 60 \% \\ \text { Civantos }^{27} & 18 & 100 \% & 100 \% & 10 \% & 9 \% \\ \text { Mozillo }^{31} & 41 & - & 95 \% & 16 \% & 0 \% \\ \text { Dunne }^{34} & 38 & - & 100 \% & 18 \% & 0 \% \\ \text { Villareal }^{30} & 22 & 100 \% & 100 \% & 25 \% & 0 \% \\ \text { Pastore } & 28 & 100 \% & 100 \% & 10 \% & 0 \% \\ \text { Ionna F. } 35 & 41 & 95 \% & 100 \% & 18 \% & 0 \% \\ \text { Estudio piloto } & 12 & 91 \% & 100 \% & \end{array}$

Table 2. Results of preliminary studies of sentinel node biopsy in oral, cavun and oropharynx cancer

\begin{tabular}{|c|c|c|c|c|c|}
\hline Authors & Patients $\left(n^{\circ}\right)$ & Loccalization of lymph & Radiolocalizacion & Hidden $\mathrm{n}^{\circ}+$ & False negatives \\
\hline Stoeckli ${ }^{24}$ & 19 & $94,7 \%$ & $100 \%$ & $31,5 \%$ & $0 \%$ \\
\hline Shoaib26 & 40 & $90 \%$ & $100 \%$ & $50 \%$ & $10 \%$ \\
\hline Civantos $^{27}$ & 18 & $100 \%$ & $100 \%$ & $60 \%$ & $9 \%$ \\
\hline Mozillo 31 & 41 & - & $95 \%$ & $10 \%$ & $0 \%$ \\
\hline Dunne $^{34}$ & 38 & - & $100 \%$ & $16 \%$ & $0 \%$ \\
\hline Villareal $^{30}$ & 22 & $100 \%$ & $100 \%$ & $18 \%$ & $0 \%$ \\
\hline Pastore ${ }^{28}$ & 20 & $100 \%$ & $100 \%$ & $25 \%$ & $0 \%$ \\
\hline Ionna F. ${ }^{35}$ & 41 & $95 \%$ & $100 \%$ & $10 \%$ & $0 \%$ \\
\hline Estudio piloto & 12 & $91 \%$ & $100 \%$ & $18 \%$ & $0 \%$ \\
\hline
\end{tabular}

cevical sólo del nivel I y II en el tratamiento cervical del cáncer oral de forma sistemática.

\section{Conclusiones}

Creemos que nuestro estudio piloto ofrece unos resultados que validaran la técnica del GC en el cáncer oral y permitirán establecer un nuevo concepto, el de la disección cervical superelectiva en los pacientes TN0 clínico al predecir la presencia de metástasis cervicales ocultas y establecer, el tipo de tratamiento cervical a seguir, y al realizar un mejor estadiaje con las técnicas de inmunohistoquímica.

\section{Bibliografía}

1. Silverman SJ. Early diagnosis of oral cancer. Cancer 1988;62:1796-99.

2. Salazar Fernández $\mathrm{Cl}$. Tratamiento quirúrgico del cáncer de lengua y suelo de boca en estadios precoces: análisis de efectividad, morbilidad y consumo de recursos. Tesis doctoral. Universidad de Sevilla, España. Facultad de Medicina, 2000.

3. Weiss MH, Harrison LB, Isaacs RS. Use of decision analysis in planning a management strategy for the stage N0 neck. Arch Otolaryngol Head Neck Surg 1994; 120:699-702.

4. Stuckensen $T$, Kovacs AF, Adams $S$, y cols. Staging of the neck in patients with oral cavity squamous cell carcinomas. A prospective comparision of $\mathrm{PET}$, ultrasound, CT and MRI. J Craniomaxillofac Surg 2000;28:319-24.

5. McGuirt WF, Greven K, Willians D, Keyes JW, Watson N, et al. PET scanning in head and neck oncology: a review. Head Neck 1998;208-15.

6. Yuasa K, Kawasu T, Nagata T, et al. Computed tomography and ultrasonography of metastatic cervical lymph nodes in oral squamous cell carcinoma. Dentomaxillofac Radiol 2000;29:238-44.
Our rate of false negatives was $0 \%$ although values in the literature are recorded between 0-10\%24-31,34,35. The contrast between our results and other broader articles that have been published, and more recently other similar studies, is reflected in table 3. Our most important finding was that all occult metastases of the neck were detected by means of a positive $S N$, and we were able to guarantee that all patients presenting a negative SN had an equally negative neck dissection. Therefore, neck dissection is only indicated in 18\% of cases and in $82 \%$ of cases it should have been avoided.

Oral cancer does not follow lymphatic draining which is scaled from level I to level IV as has been thought conventionally, rather individual lymphatic draining takes place as shown in the different levels of the SNs: $27 \%$ of our patients presented individual lymphatic draining with «level jumps». Ionna et al. ${ }^{35}$ in their series with 41 patients with T1-2 tongue and floor of the mouth cancer found a «jump in scale» in 18\% of cases, coinciding with similar levels reflected in the literature. ${ }^{24,26-27,29,31-}$ 34 Therefore systematic neck dissection is not justified for only level I and level II in neck treatment of oral cancer.

\section{Conclusions}

We believe that our pilot study promises results which will validate the SN technique in oral cancer and which will allow the establishment of a new concept, that of superelective neck dissection in clinical TNO patients on predicting the presence of occult neck metastasis and establishing the type of neck treatment to follow, and on making better staging with immunohistochemical techniques. 
7. Hodder SC, Evans RM, Patton DW, y cols. Ultrasound and fine needle aspiration cytology in the staging of neck lymph nodes in oral squamous cell carcinoma. Br J Oral Maxillofac Surg 2000;38:430-6.

8. Hao SP, Ng SH. Magnetic resonance imaginig versus clinical palpation in evaluating cervical metastasis from head and neck cancer. Otolaryngol Head Neck Surg 2000;123:324-7.

9. Mack MG, Balzer JO, Straub R, Eichler K, Volg TJ. Superparamagnetic iron oxide enhanced MR imaging of head and neck lymph nodes. Radiology 2002;222:239-44.

10. Morton DL, Duan-Ren W, Wong JH, Economous JS, Cagle LA, Storm FK, y cols. Technical details of intraoperative lymphatic mapping for early stage melanoma. Arch Surg 1992;127:392-9.

11. Thompson JF, McCarthy WH, Bosch CMJ. Sentinel lymph node status as an indicator of the presence of metastatic melanoma in regional lymph nodes. Melanoma Res 1995;5:255-60.

12. Albertini JJ, Cruse CW, Rapaport D. Intraoperative radiolymphoscintigraphy improves sentinel lymph node identification for patients with melanoma. Ann Surg 1996;223:217-24.

13. Alex JC, Krag DN. Gamma-probe-guided localization of lymph nodes. Surg Oncol 1993;2:137-44.

14. Alex JC, Weaver DL, Fairbank JT. Gamma-probe-guided lymph nodes localization in malignant melanoma. Surg Oncol 1993;2:303-8.

15. Alex JC, Sasaki CT, Krag DN, Wenig B, Pyle PB. Sentinel lymph node radiolocalization in head and neck squamous cell carcinoma. Laryngoscope 2000;110:198-203.

16. Taylor RJ, Wahl RL, Sharma PK. Sentinel node localization in oral cavity ond oropharynx squamous cell cancer. Arch Otolaryngol Head Neck Surg 2001;127: 970-4.

17. Waddington WA, Keshtgar MRS, Taylor I, Lakhani SR, Short MD, Ell PJ. Radiation safety of the sentinel lymph node technique in breast cancer. Eur J Nucl Med 2000;27:377-91.

18. Van Diest PJ, Peterse HL, Borgstein PJ. Pathological examination of sentinel lymph nodes. Eur / Nucl Med 1999;26:43-9.

19. Gennari R, Stoldt HS, Bartolomei M, Zurrida S, Testori A, Mazzarol G, $y$ cols. Sentinel node localization: a new perspective in the treatment of nodal metastases. Int / Oncol 1999;15:25-32.

20. Meyers JS. Sentinel lymph node biopsy: strategies for pathologic examination of the specimen. / Surg Oncol 1998;69:212-8.

21. Turner RR, Ollila DW, Krasner DL, Giulliano AE. Histopathologic validation of the sentinel lymph node hipótesis for breast carcinoma. Ann Surg 1997;226:271-8.

22. Baatenburg de Jong RJ, Rongen RJ, Verwoerd CD, Overhagen H, Lameris JS y cols. Ultrasound-Guided fine needle aspiration biopsy of neck nodes. Arch Otolaryngol Head Neck Surg 1991;117:402-4.
23. Martínez Gimeno C, Moro Rodríguez E, Navarro Vila C, López Varela C. Squamous cell carcinoma of the oral cavity: a clinicopathologic scoring system for evaluating risk of cervical lymph node metastasis. Laryngoscope 1995;105:728-33.

24. Stoeckli SJ, Steinert H, Pfaltz M, Schmid S. Sentinel lymph node evaluation in squamous cell carcinoma of the head and neck. Otolaryngol Head Neck Surg 2001;125:221-6.

25. Pitman KT, Johnson JT, Edington H. Lymphatic mapping with isosulfan blue dye in squamous cell carcinoma of the head and neck. Arch Otolaryngol Head Neck Surg 1998;124:790-3.

26. Shoaib T, Soutar DS, Prosser JE, McDonald DG, Dunaway DJ, Gray $\mathrm{HW}, \mathrm{y}$ cols. The accuracy of head and neck cercinoma sentinel lymph node biopsy in the clinically N0 neck. Cancer 2001;91:207783.

27. Civantos FJ, Gomez C, Duque C, Pedroso F, Goodwin WJ, y cols. Sentinel node biopsy in oral cavity cancer: correlation with PET scan and inmunohistochemistry. Head Neck 2003;25:1-9.

28. Pastore A, Turetta GD, Tarabini A, Turetta D, Feggi L, Pelucchi S. Sentinel lymph node analysis in squamous carcinoma of the oral cavity and oropharynx. Tumori 2002;88:S58-60.

29. Shoaib T, Soutar DS, Prosser JE, Dunaway DJ, Gray HW, y cols. A suggested method for sentinel node biopsy in squamous cell carcinoma of the head and neck. Head Neck 1999;21:728-33.

30. Villareal Renedo PM, Rayo Madrid I, Pimentel Leo JJ, Serrano Vicente J, y cols. Estadiaje cervical mediante biopsia de los ganglios centinelas cervicales en el carcinoma de células escamosas de cabeza y cueIlo. Rev Esp Cirug Oral y Maxilofac 2002;24:223-35.

31. Mozillo N, Chiesa F, Botti G, Caraco C, Lastoria S, y cols. Sentinel node biopsy in head and neck cancer. Ann Surg Oncol 2001;8(suppl 9):103 S-105S.

32. Ross G, Shoaib T, Soutar DS, Camilleri IG, Gray HW, Bessent RG, Robertson AG y cols. The use of sentinel node biopsy to upstage the clinically NO neck in head and neck cancer. Arch Otolaryngol Head Neck Surg 2002;128:1287-91.

33. Barzan L, Sulfaro S, Alberti F, Politi D, Marus W, Pin M, y cols. Gamma probe accuracy in detecting the sentinel lymph node in clinically NO squamous cell carcinoma of the head and neck. Ann Oto Rhinol Laryngol 2002; 111:794-8.

34. Dunne AA, Kulkens C, Ramaswamy A, Folz BJ, y cols. Value of sentinel lymphonodectomy in head and neck cancer patients without evidence of lymphogenic metastatic disease. Auris Nasu Larynx 2001;28: 339-44.

35. Ionna F, Chiesa F, Longo F, Manola M, Villano S, y cols. Prognostic value of sentinel node in oral cancer. Tumori 2002;88:S18-19. 